THE EUROPEAN JOURNAL OF LIFE WRITING VOLUME VII(2018)CP90-CP110

\title{
Jacques Presser, Egodocuments and the Personal Turn in Historiography
}

\section{Arianne Baggerman and Rudolf Dekker}

Although they belong to different generations of scholars, Philippe Lejeune and the Dutch historian Jacques Presser (1899-1970) have much in common. Both have chosen autobiographical writing as a main focus of research, and this at times when this type of texts was hardly seen as a serious subject, both in literary studies and in history. Both felt a need to create order in this unexplored but rich field. And with this in mind, both have proposed new definitions while being aware that autobiographical writing has always resisted narrow enclosures. They both were drawn to the same theoretical problems, such as the overlap between fiction and life writing. Both have written about the same texts, such as the diary of Anne Frank and the work of Jean-Paul Sartre. And, finally, both did not hesitate to introduce their own ' $I$ ' in their texts. One difference remains: Jacques Presser never had the time to write a comprehensive study on the subject, and his ideas were mainly transmitted through his students; while Philippe Lejeune has, since the appearance in 1971 of his L'autobiographie en France, built an impressive and influential oeuvre. The resemblances and differences between these two scholars obviously merit further study.

In 1963 Jacques Presser started writing his autobiography by confessing that he did not know what the result would be. About one thing, however, he was certain, his book should not be his memoirs but his autobiography. He wanted to put his own life — 'this ego' — in the centre. Thus, an autobiography about himself instead of memoirs about the people he had met during his life. Presser knew what he was writing about. 'I have been working over the years with all sorts of historical sources, and I have isolated one specific type, which I called ego-document: autobiographies, memoirs, diaries, letters and so on, in short all written sources, in which 
we meet a man more clearly, more personally, than in other sources, and who thus becomes to us instead of a "nameless human" - whatever that might be - a distinctive ego'. Presser abandoned the project after he had written about the first twenty years of his life. Only fifteen years after his death in 1970 were these memories of youth published. ${ }^{1}$

Presser was born in Amsterdam in 1899 to Jewish parents with socialist sympathies, living in the middle of the Jewish quarter at the Waterlooplein, a busy marketplace. ${ }^{2}$ His father worked in the diamond industry and was only a bit better off than the rest of a very poor family. After a few years in Antwerp, the family returned to Amsterdam. Around that time Presser's first name had changed from Jacob to Jacques. With the financial support of the father of a friend Presser started to study history and Dutch literature and language at the University of Amsterdam. In 1926 Presser became a teacher at the Vossius Gymnasium in Amsterdam. ${ }^{3}$ This was the newly founded second gymnasium of the city, soon called the 'school van Joden en Roden', the 'school of Jews and Reds'. After the German occupation in May 1940 Presser, like all Jewish teachers, lost his position. From 1941 to 1943 he was a teacher at Joods Lyceum, a school created for Jewish children, who were now also banned from schools. Then Presser's wife, Deborah (Dé) Appel, a former student at the Vossius Gymnasium, was caught while travelling without a Star of David and with a false identity card. She was transported to Westerbork transit camp and eight days later murdered in Sobibor. Presser went into hiding and survived. After the war, Presser briefly returned to the Vossius Gymnasium and was in 1947 appointed professor at the University of Amsterdam in the Faculty of Political and Social Sciences, despite the opposition of the government because of his left-wing reputation and his Marxist or at least what later would be called Marxisant approach to history. ${ }^{4}$ In 1959 Presser was appointed to a chair in the Faculty of History, at the Historisch Seminarium.

Around this time, Jacques Presser was a well-known public intellectual. He published widely in the Dutch press on literature, history and politics. He also wrote poetry, short stories and detective novels. ${ }^{5}$ In his unfinished autobiography Presser explained that his interest in autobiography and biography, and the personal element in history in general, was a reaction to the Marxist interpretation of history with its emphasis on abstractions like 'developments' and 'masses'. This influenced his choice of subjects of study, which included a biography of Napoleon Bonaparte, which was to a large extent based on memoirs, letters and other personal records. In this debunking biography, subtitled 'history and legend', written in 1939 and published in 1946, Presser emphasised the totalitarian side of the French emperor. ${ }^{6}$ 
After the war, Presser was involved in publishing the diary of Anne Frank. The diary was found by one of the helpers after the family was arrested in their hiding place and was in 1945 returned to Anne's father, the only survivor of the family. Otto Frank made a slightly edited typescript of his daughter's diary and asked the well-known historian Jan Romein if he saw a possibility for publication. Presser also read the manuscript before it was published. After the book came out in 1947, with a foreword by Romein's wife Annie Verschoor, Presser wrote one of the first reviews not only stressing the importance of the diary, but also praising Anne's style of writing. ${ }^{7}$ Later Presser edited another war diary, kept by Philip Mechanicus in camp Westerbork, from where Dutch Jews were sent to the extermination camps. ${ }^{8}$

In 1950 Jacques Presser was commissioned by the Dutch government to write a book about the persecution of the Dutch Jews during the German occupation. He was asked to undertake this task by a former student at the Vossius Gymnasium, Lou de Jong, who was after the war appointed director of the RIOD, Rijks Instituut voor Oorlogsdocumentatie, now the NIOD, Institute for War, Holocaust and Genocide Studies. Presser worked for fifteen years on this book. The result was Ondergang. De vervolging en verdelging van het Nederlandse Jodendom, 1940-1945, published in $1965 .{ }^{9}$ An English translation followed three years later, titled Ashes in the wind. ${ }^{10}$

Presser's research included, besides archival sources, many diaries, memoirs and letters. In the chapter on documentation Presser wrote that it was necessary to make as much use as possible of "the kind of sources, for which we have introduced the collective term "egodocument". $\mathrm{He}$ wanted 'to confront the reader continually with the experiences, thoughts and feelings of individual persons.' ${ }^{11}$ He made use of the hundreds of diaries collected by the NIOD. In March 1944 the Dutch government in exile in London had broadcast through Radio Oranje a call to all Dutchmen to keep a diary to document the German occupation. After the war had ended in May 1945, director Lou de Jong invited diarists to send their manuscripts to the NIOD to be photocopied. Although about a third of all manuscripts were returned, as they were judged lacking interest, an important collection was formed. ${ }^{12}$ In 1954 a selection of fragments from these diaries was published, which was twice reprinted within a year..$^{13}$ At the moment the collection contains 1527 diaries and memoirs, and is still growing. In 2016 some 70 diaries were received, about the average number in recent years. Hundreds or more likely thousands of wartime diaries are still privately owned.

Presser also conducted hundreds of interviews with both survivors and executors of the Holocaust. He met with men and women whose memories were so painful that they were unable or unwilling to recall anything, 
but he also spoke with people who deliberately falsified their past. This made him more aware of the problems of oral history as a method and the use of egodocuments. At the time Ondergang came out, in 1965, Presser's personal, subjective approach and his attention to individual experiences received a rather critical response from his colleagues. The reading public thought differently, and the book was reprinted eight times. After the publication of Ondergang Presser did not find time to write other books he had in mind, which probably would have included a general study on egodocuments.

Jacques Presser only published three short texts on the genre he had defined as egodocuments. The first is an entry in a Dutch encyclopaedia in 1958 in which he defined egodocuments as "those historical sources in which the researcher is faced with an "I", or occasionally (Caesar, Henry Adams) a "he", as the writing and describing subject with a continuous presence in the text'. ${ }^{14}$ In his farewell lecture in 1969 he spoke more succinctly of 'those documents in which an ego deliberately or accidentally discloses or hides itself' ${ }^{15}$ Finally, in 1970, an article on Jews and diary writing was published posthumously. ${ }^{16}$ Presser had since 1951 taught a course called 'Ego document' for 'kandidaten', master-students, a group of usually about forty students. Several of his students became well-known scholars, like J.J. Oversteegen, J.M. Pluvier, Rena Mansfeld, Eco Haitsma Mulier, Piet de Rooy, Nicolette Mout, Maarten Brands, Jan Bank and Piet Blaas. Presser's own preparation notes and the notes kept by some of his students make it possible to reconstruct his lectures. In later years he was assisted by a colleague at the Historisch Seminarium of the University of Amsterdam, Philip de Vries, who had been a former student at the Vossius Gymnasium. ${ }^{17}$

\section{JACQUES PRESSER AND HIS COURSE 'EGODOCUMENTS’}

In the academic year 1951-1952 Jacques Presser taught for the first time the course for which he had invented the word 'ego-document'. ${ }^{18} \mathrm{He}$ wrote the word with a hyphen, which would later disappear. In 1976 the word was included in the standard Dutch dictionary, Van Dale groot woordenboek der Nederlandse taal. ${ }^{19}$ Presser taught this course on egodocuments until his retirement in 1969, but within this broad field he changed topics each year. In the years 1953-1954 and 1954-1955 the subject was German 'ego-historiography', and titled 'Ego-documenten uit de Hitler-tijd, 19331945': 'I do not know another period of whatever "Reich", which has produced so many egodocuments as the Third Reich'. He explained that official archives were insufficient, if only 'because Hitler did much outside 
the official channels'. Mein Kampf was also discussed as an autobiography during this course. In other years themes were the letter or the diary and in the year 1966-1967, for instance, the course theme was French diaries. Each year he updated the course adding new insights and new literature, such as Gustav René Hocke's Das europaeische Tagebuch (1963), 'the first serious study in the field'. ${ }^{20}$ He mentioned the work of George Misch, but at a time when only his work on autobiography in Antiquity was published, adding 'as far as I know he did not continue this work, which is very, very regrettable, as this is very good in its kind'. ${ }^{21}$ Presser pointed at the difficulty in the 1950s to find literature in bibliographies and catalogues, while many books were not available in the Netherlands. The relationship between diary writing and the changing perception of time received attention in the course in the 1960s discussing books like Georges Gurvitch's The spectrum of social time (1964). ${ }^{22}$

The heading of Presser's notes for the first course is: "College Egodocument". Presser started with introducing the word he had invented, stressing that he used it 'for want of something better'. He also admitted that it is difficult to establish the limits of the term: 'In fact everything is egodocument'. In later years he mentioned some key forms ('kernvormen'): 'autobiography, memoirs, diary, letter, travel journal, confession, testament, conversation'. The border with literature was a problem in itself. As 'a good concrete example' Presser discussed a novel published in 1947 by a former student at the Vossius Gymnasium, Gerard Kornelis van het Reve, De avonden, now regarded as one of the greatest Dutch novels of the twentieth century. Presser told his students that he could personally assess its autobiographical character, which included the school and several of its teachers and former students. ${ }^{23}$ Presser had received a copy with a personal dedication from the young author. ${ }^{24}$ According to Presser there was even an open border with music: 'In some sense everything here is historical egodocument' with the examples of Smetana's string quartet 'From my life' and Janacek's 'Intimate letters'. Finally he advised his students not to take the word egodocument too literally, as some of these texts were written in the third person.

The first time Presser taught this course he started by stressing that the field was 'very unexplored' and that egodocuments were 'a neglected subject'. He told his students that while preparing the course he had discussed the subject with three colleagues. The first was Jan Romein, who was certainly aware of the value of such sources. Romein had, before it was published, pointed out the importance of Anne Frank's diary in an article on the front page of the newspaper Het Parool: 'To me this seemingly insignificant diary of a child, this 'de profundis' stammered by a childish voice, shows all the hideousness of fascism, more so than all the 
records of the Nürenberg trials taken together'. ${ }^{25}$ In his notes however, Presser wrote after Romein's name (in fact he only used his initials): 'not he'. Maybe this was because Romein also had reservations about the use of egodocuments, which he had called 'the most dangerous of all sources'. ${ }^{26}$ The others were Henk Hoetink, law professor at the University of Amsterdam, well-known for his erudition, and Gerrit Kalff jr. ${ }^{27}$ Kalff had in 1935 published a survey of Dutch diaries, which is still the only book in this field. ${ }^{28}$ Presser added a personal detail: Kalff had kept a very extensive diary which he had bequeathed to the city archive of Amsterdam placed under embargo until the year 2000. ${ }^{29}$

In his courses Presser mentioned the existing international literature on the subject, but he stressed the 'complete imbalance between production and the analytical or descriptive studies on this genre'. More than half a century later it is hard to imagine how little scholarly interest had gone to autobiography, diary and comparable genres before around 1970. Presser mentioned that the popularity of the genre was increasing: 'The love for this genre is widespread and growing, also among the general public'. In the first meetings Presser sketched a theoretical perspective using some of his favourite authors, including Nietzsche ('without forgetting one cannot live'), Freud ('forgetting is more enigmatic than remembering') and Bergson ('la mémoire qui répète' and 'la mémoire qui révoit'). Presser also mentioned George Gusdorf's great study La découverte de soi, which was published in $1948 .{ }^{30}$ For the neighbouring genre of the biography Presser referred to Jan Romein's De biografie from 1946 and a few years later also to Sem Dresden's De structuur van de biografie from $1956 .{ }^{31}$

The history of the types of texts within the umbrella of the word egodocuments was treated by Presser mainly by discussing the texts themselves. He saw himself rightfully as a pioneer and said to his students that his lectures were 'based on years of reading, which were finally brought a bit into a system'. The problems of egodocuments when used as a historical source were also discussed with concrete examples. Presser brought in a few crown witnesses: Samuel Pepys and his 'external' diary and Henri Frédérique Amiel and his 'introspective' diary. Stendhal was often mentioned as writer of 'the pinnacle of a functional diary'. Of course Anne Frank's diary was discussed, for instance as an example of a diary written for future readers. Among the often mentioned autobiographers are Montaigne, Cellini, Goethe, Berlioz and some modern writers, like George Santayana.

Presser used to bring piles of books to the lecture room, encouraging his students to read them. He also said that they should look beyond texts written by famous authors or important persons: 'Memoirs of actresses 
and chansonnières, like Mistinguett and so on. ${ }^{32}$ Do not look down on them, there are jewels, like Miss Billie Holiday, the greatest of all bluessingers'. ${ }^{33}$ Most of Presser's examples came from France, Germany, England and the United States. In his lecture notes he wrote: 'In the Netherlands not much is produced in the past, few diaries'. This was also the conclusion of Gerrit Kalff in his survey. Of the Dutch diaries, Presser mentioned those by Constantijn Huygens jr from the seventeenth century and by Willem de Clercq from the nineteenth century, both being exceptions to the rule. ${ }^{34}$

A recurring item during the course was the question to what extent egodocuments, consciously or unconsciously, differ from the real deeds and thoughts of the author. How reliable was human memory, and how trustworthy were the authors? During the first meeting of the course in 1958/9 Presser discussed the problems involved in writing a history of the German concentration camps based on the memories of survivors. His student Ed van Thijn made the following note: 'Camp history. Difficulty: has the ego remained intact? Depersonalization. People were living in such a different sphere. A kind of hereafter atmosphere. Incredible unreal (for example the love of truth disappeared, was one allowed to lie to Germans?). One owns pistols and is ashamed of it in normal life. "I have done this, memory tells me. I cannot have done that, my pride tells me. But finally my memory wins" (Nietzsche)'.

This was a problem with which Presser was struggling himself while writing Ondergang. Presser cited Santayana as an example of an autobiographer who was aware of this question. 'We do not twist, conceal or falsify the past', Presser said, and cited a passage from Persons and places: 'A point of view and a special lighting are not distortions. They are conditions of vision, and spirit can see nothing not focused in some living eye'. ${ }^{35}$ The autobiographer's memory can never create a replication of the past. Even the diary is 'not a fair registration of life' said Presser: 'We shape a fictive "I" and from that personality we assess our experiences'. Presser's conclusion is simple: 'Be careful using a diary as a source'. In passing he pointed out the danger of the telephone: 'the telephone is not recorded in writing', although he mentions the possibility of 'wire recording'. Nevertheless, he was convinced that in his own time more diaries were kept than ever before. He also gave an explanation: 'In our world time is dynamic, accélération de l'histoire, there is another tempo of life than in the past'. ${ }^{36}$

Falsification of egodocuments was given much attention by Presser. His fascination goes back to his dissertation from 1926, Das Buch 'De tribus impostoribus' (vom den drei Betrügern), the demythologisation of a non-existing book supposedly published in 1598, in which Moses, Jesus and Mohammed are exposed as impostors. Presser called the fake diary 
'a delightful genre'. If the falsification was based on real material it could still be a useful source. He mentioned the example of the memoirs of Joseph Fouché, Minister of Police under Napoleon, published in 1824 and later attributed to Alphonse de Beauchamps: 'useful to careful historians'. ${ }^{9}$ He also discussed some Dutch examples. ${ }^{38}$

Another example was 'The Diary of a Public Man', written by an anonymous insider in the American government in 1860-1861, which was in 1879 published in the North American Review. About the many attempts to discover the identity of the author Frank Maloy Anderson had in 1948 published The mystery of "A Public Man". A historical detective story. ${ }^{39}$ Presser also mentioned the 'diary' of Soviet-minister Maksim Litvinov, Notes for a journal, published by E.H. Carr in 1955 and the discussion that followed. Presser's conclusion was: 'They have all been fooled' ${ }^{40}$ Presser briefly mentioned what he called the products of 'an international gang of translators, publishers, writers and so on', who produced mainly anti-communist works like I was Stalin's bodyguard. ${ }^{41}$ With his left-wing sympathies Presser detested such books all the more. Even worse was Le journal intime d'Eva Braun: 'worthless, stupid nonsense; how is it possible that anybody could believe this'. ${ }^{42}$

The blurred border between egodocument and fiction is another fascination of Presser. He mentioned more than once La nausée by Jean-Paul Sartre, 'one of the most splendid diaries' and 'a glorious masterpiece'. ${ }^{43}$ His student Ed van Thijn added: 'Read!' Presser summarised the book: 'A historian who broke off his life as a scholar to create artistic work'. This must have appealed to Presser, who had been a teacher and wrote poetry. Fictionalising was in his view no crime. He told his students: 'Truth is important, truthfulness no less'.

According to Presser a diary could be a work of art. A diary was a more supple textual form than the novel. 'Could this be related to the loosening of literature?' asked Presser of his students. He saw the diary as a 'break with the current literature'. The genre was attractive because of 'the tempo of observation and the immense variety of what can be observed'. In short: 'The diary is the solution for the modern writer'. He then gave some examples of real diaries that are considered as literature, like those written by Ernest Renan, Paul Valéry and André Gide. Another example of a literary diary was written by a writer and politician of the German Democratic Republic (DDR) Johannes R. Becher, Aus andere Art so grosse Hoffnung kept over the year $1950 .{ }^{44}$

To gain more insight into the difference between fictive and authentic diaries Presser discussed The wall by John Hersey, published in 1950, a fictive diary from the Warsaw ghetto in 1943, 'a brilliant work'. ${ }^{45}$ Presser supposed that in the ghetto many diaries were written, but that these were 
burned when the Ghetto Uprising was crushed. However, one did survive, kept by Emmanuel Ringelblum, of which in 1958 an English translation was published. ${ }^{46}$ Presser compared Hersey's novel with Ringelbaum's diary and asked his students the following questions: 'Is the approach of Hersey justified to give us an impression of the Warsaw Uprising? After reading Ringelblum Hersey does not bring anything new. Why did Hersey write a novel instead of an historical study?' Presser also made critical notes, Hersey had turned Eastern Jews into Western Jews, and the Polish government had censored the original edition of Ringelblum's diary by diminishing the part of the Jews in the resistance.

The question to what extent editors have shortened, censored or rewritten authentic manuscripts, is also discussed. One example is the many editions of the diary of Samuel Pepys, of which in the 1950s still no completely uncensored edition was available, as the first unexpurgated text was published only after 1970. Presser warned his students: 'You can never trust the editor of a diary'. Various other questions were brought up by Presser in these courses spread over two semesters during a full academic year. In later years he also gave public lectures on the subject. Presser's farewell lecture in 1969 was an ultra-short summary of the courses he had given since 1950 and a defence of the use of egodocuments as historical sources.

\section{AUTOBIOGRAPHICAL ASPECTS IN PRESSER'S WORKS}

Presser's predilection for egodocuments goes back to his years as teacher at the Vossius Gymnasium, when he wanted to enliven his lessons with anecdotes. It was helpful that he was already an enthusiastic reader of the genre and valued the aesthetic character of such texts. As a professor Presser still defended the traditional illustrative function of egodocuments in history writing. In 1958 he wrote that this inevitable subjective approach could 'bring dead material to life' with all sorts of details, while the human element made 'emotions tangible'. Presser was no theoretician like his colleague Jan Romein, and, on the contrary, feared that in modern historical studies the analysis would overshadow the description of the past. This was also his main concern about Marxist historians using rigid schemes. Maarten Brands, student and assistant of Presser and thereafter colleague, suggested that Presser was also fascinated by the complexities of the ego's presented by autobiographers and diarists, being aware of his own personality with its own complexities and paradoxes, such as his wish to be loved combined with his tendency to keep people at a distance. ${ }^{47}$ 
In Ondergang Presser did much more than using egodocuments and personal testimonies as illustrations. Autobiographical material is in fact at the centre of the book. His use of egodocuments was later widely adopted by historians of the Holocaust. Saul Friedländer pointed out the special importance of post-war depositions, interviews and memoirs, and the 'unusually large number of diaries (and letters) written during the events'. They have to be used with critical attention, but they 'remain crucial and irreplaceable'. 'The victim's voice', Friedländer writes, 'can tear through the fabric of the "detached" and "objective" historical rendition'. The voices of individual victims "introduce into the most precise historical narrative a primary and essential sense of disbelief' ${ }^{48}$ This is exactly what Presser had aimed at while writing Ondergang.

Ondergang is a very personal book and the author is always present in the text as 'the author', 'the historian' or 'we', which was unusual for historians and even a taboo in a scholarly work. Students at the Historisch Seminarium of the University of Amsterdam were at that time instructed never to use the word "I" in their papers. Presser was also present in the text in his personal phrasing and style, and in his case le style c'est l'homme was very true. Presser was in this way a predecessor of later scholars, especially those who were using and studying egodocuments, with as example par excellence Philippe Lejeune. ${ }^{49}$ Nearly fifty years after Presser's death we can conclude that history writing did eventually have a personal turn.

Presser was criticised for his personal approach and his style was seen by some as rhetorical and pathetic. Presser would agree, and said: 'This book is really written with blood'. During the fifteen years spent researching and writing Presser, as he admitted, could not have a single conversation with a Jew without mentioning the subject. The book in progress was also now and then mentioned during his courses. Among the interviewed were many friends and acquaintances within his own circle. He also interviewed some of his students and former students at the Vossius Gymnasium. When Presser was aware that his student Ed van Thijn was a war orphan he invited him for an interview. Many years later Van Thijn wrote in his memoirs: 'With trembling knees I arrived at Presser's home, who received me in his much too small study, packed with piles of books. He set me soon at ease with his legendary friendliness and asked me to tell my story. The story which I never had been able to tell anyone [...]. I talked for more than two hours constantly. Presser, who did not interrupt me once, wrote everything down, while tears trickled down his cheeks. When I was finished, he looked at me intensely and said: "You should write this down". ${ }^{50}$ Van Thijn did indeed write his story, but only forty years later in another book titled Achttien adressen, eighteen addresses, the number of homes where he had been hiding and had survived the Holocaust. ${ }^{51}$ 
In Ondergang Presser also made use of a diary kept by a former student at the Vossius Gymnasium, David Koker, who had not survived. Koker was detained for a year in the Dutch concentration camp Vught, and his diary is not only a factual source, but also a very perceptive account of life and relations in this camp. This diary is in the NIOD collection, and was published in 1977 by a former student of Presser, Karel van het Reve. ${ }^{52}$ After Ondergangwas published, Presser mentioned during his course his experiences as author, and the many reactions he received. In his teaching notes for the year 1966-1967 he wrote: 'How strange it is to see your image on television, experience full of unrest, uneasy, fearful...'

Since Ondergang was published many other war-time diaries have been published, which were unknown to Presser. Another former student of the Vossius Gymnasium, Hanny Michaelis, wrote a diary during the full five years of the German occupation. Presser is several times mentioned in the text. Hanny Michaelis, who was after the war for a time married to Gerard Kornelis van het Reve, wrote one of the most important and perceptive diaries kept in these years. ${ }^{53}$ And there are many more examples. ${ }^{54}$ There are probably hundreds, if not thousands, of war-time diaries and letters still kept by descendants of the writers.

Historians had criticised Ondergang for being too much based on personal testimonies in general, but soon the discussion focused on one case, that of Friedrich Weinreb. As a child Weinreb, born in 1910 in Lemberg (Lviv), had come to the Netherlands with his Chassidic family. During the German occupation he created a list which barred Jews from deportation under the protection of a fictive German general. In the end this list did not offer protection, and after the war Weinreb was convicted as swindler and traitor. Presser, who stressed the importance of Jewish resistance, saw Weinreb, despite some reservations, mainly as a scapegoat: 'If there were no Jewish traitors, they had to be invented'.

In 1969, four years after the publication of Ondergang, Weinreb published his memoirs in three volumes, together nearly two thousand pages. ${ }^{55}$ Weinreb's memoirs were edited by a well-known writer and journalist, Renate Rubinstein, a former student of the Vossius Gymnasium. She compressed his more than 3000 handwritten pages to 2000 printed pages. Presser had introduced her to Weinreb, and he, enthusiastic about the project, told his students 'Weinreb has started writing his memoirs'. He also wrote a short preface, in which he repeated what he told his students, memoirs are always a reconstruction in which the author 'forgets, represses and forges' the past. Weinreb, however, had according to Presser the gift of presenting the past as if it was the present. The book was a best-seller because these memoirs fitted perfectly in the spirit of protest of the 1960s. Weinreb was seen as a precursor of the Dutch Provos. 
However, not everybody was convinced. Writer W.F. Hermans started a campaign to expose Weinreb. His interest in the case might have been related to a novel he had published in 1958 about treason and deception during the German occupation. The main character is a man who becomes involved in the resistance, but is after the war arrested for collaboration. It is left to the reader to decide whether he is a hero or a traitor. ${ }^{56}$ Separately, journalist Henriëtte Boas challenged the sincerity of Weinreb and the truthfulness of his story. ${ }^{57}$ Finally the government ordered the NIOD to investigate the matter again. The result of this investigation appeared in 1976 in a report of 1684 pages, which concluded that Weinreb had distorted the truth in his memoirs and that he had been rightly convicted after the war. ${ }^{58}$ This conclusion was generally accepted with a few exceptions. Aad Nuis, who had in 1955-1956 followed Presser's course on egodocuments, and had been married to Renate Rubinstein, published a short defence of Weinreb. ${ }^{59}$ Presser did not participate in the discussion and would die within a year after the publication of Weinreb's memoirs, but he did agree to leave out the paragraph on Weinreb in the English translation of Ondergang. Today, Weinreb's memoirs are reduced to an example of the problem of fact and fiction in egodocuments, while the author became the subject of psychological research. ${ }^{60}$

During the last two years before his retirement Presser's course on egodocuments was replaced by what he announced in the guidebook of the university as 'A historian makes a book'. Presser talked about Ondergang, without having made lecture notes. Students remember this course as 'a hesitating and emotional account' about the making of his magnum opus. ${ }^{61}$

Jacques Pressor saw himself not only as a historian, but also as a poet and a writer. He published poems and wrote a few detective novels, one of which is set at the University of Amsterdam, Moord in de Poort in $1965 .{ }^{62}$ The 'Poort' or officially Oudemanshuispoort is the main building of the university, where Presser gave his public lectures. En passant he made fun of new studies, including extrasensory perception. The detective is a professor in medicine who is worried about such developments and about the influence of captains of industry. He feared that his university would become 'a pseudo-university like an American college'. Again Presser was ahead of his time and foreseeing future developments.

In two publications Presser himself crossed the line between egodocument and fiction. During the years he was in hiding he wrote a novel about his own situation, which he titled Homo submergus, the submerged man, or man in hiding. The main character is very close to Presser, and the happy ending is a reunion with his lover, bearing the same name as his wife, Dé. At the time of writing Presser still fostered the hope that his 
wife would return from the extermination camps. The manuscript was refused by the publishing house Querido, which had also refused Anne Frank's diary. Later Presser said he did not want to publish the manuscript, because too many people could recognise themselves. Thereafter the manuscript was thought to be lost, until it emerged and was published in $2010 .^{63}$

In 1957 Presser wrote a novella, De nacht der Girondijnen. To write a short story on the topic of his research was suggested to Presser by Loe de Jong as a means to overcome his writer's block. Presser had sent in the manuscript as an entry to a competition organised by the branch association of publishers, book-sellers and printers. Since the 1940s its Committee for the Promotion of the Book invited Dutch writers to send in short texts anonymously with a motto for identification. Presser's motto was 'Homo homini homo', a play on the dictum 'homo homini lupus'. Presser was invited among several other writers to send in a short text by the secretary of the Committee, a former student at the Vossius Gymnasium. Presser's novella was chosen out of 45 entries. De nacht der Girondijnen was published anonymously being the subject of a competition for its readers. The book was published as a gift to book buyers during the yearly Week of the Book. Those who identified the author correctly could win a prize. All authors who had submitted a text were listed in an appendix to the publication. Besides Presser's name the reader would find some wellknown authors like Theun de Vries, Elisabeth Zernike, Johan Fabricius and Hélène Nothenius. In these years these gift books were published in a print-run of around 150,000 copies, an astonishing number in a country with a population of only eleven million. Once the name was revealed, its author had reached national fame. ${ }^{64}$

The leading character of De nacht der Girondijnen is an assimilated Jewish teacher in the Dutch transit camp of Westerbork, assisting a guard of the Jewish camp police to select Jews for transport. There is much of Presser himself in the main character. Presser told Philo Bregstein that the character was a combination of a colleague and himself, including his first name Jacques and his birthday. To this could be added his ambivalent attitude to his Jewishness. ${ }^{65} \mathrm{He}$ must have had in mind the time he was a teacher at the Jewish Lyceum, where his pupils were either being deported or went into hiding. Realising that, being a Jew, he is bound to share the fate of those he had sent away, he detests his own cowardice, and finally beats a camp guard. Placed in the Penal Block he shows his diary to a woman he knows. She had been caught with a false identity card. Her name was Dé, the name of Presser's wife, and this was what had happened in reality to Presser's wife. Dé reads Jacques' diary before it is smuggled out of the camp. Together they will be deported on the next train to 
Sobibor. While he comforts her, he is thinking of the French Girondists, who held each other's hand while being transported to the guillotine.

In contrast to Homo submergus this novella has a sad ending, which also brings to mind the failed suicide attempt of Presser and his wife in May 1940 after the Germans had occupied the Netherlands ${ }^{66}$ But the ending is not only sad, as for Presser in rewriting the past, this virtual sharing of his wife's fate must have been a relief. Writing the novella helped him to live with his personal trauma and to overcome his writer's block.

De nacht der Girondijnen was translated into several languages. The Italian translation appeared in 1967 with a foreword by Primo Levi. ${ }^{67}$ A French translation was originally planned, at the initiative of Claude Lanzmann who had read the English translation, and was scheduled to appear in Les Temps Modernes. However, the text was refused without explanation. The book appeared at another French publisher and was presented in the Centre Pompidou on 19 November 1990. At this presentation a collaborator of Lanzmann stepped forward to criticise the book and said that Presser was an impostor, because he had not been in camp Westerbork. Obviously, Lanzmann had thought that the book was autobiographical, while in his view the Holocaust should never be treated in fiction. ${ }^{68}$ Another criticism was that Presser had borrowed from two letters written by Etty Hillesum, which were already in 1944 published by the resistance press during the German occupation. Presser, however, had said clearly that these letters had been a source of inspiration. He later mentioned Hillesum's letters in Ondergang, and called them 'never surpassed in their sort'. ${ }^{69}$ A complete edition of her letters was only published in $1981 .^{70}$

\section{PRESSER AS AUTOBIOGRAPHER}

Jacques Presser was highly regarded and liked by everybody. He was probably the most popular teacher at the Vossius Gymnasium and later on his public lectures at the university attracted full rooms. Through the press, radio and television he became a well-known public intellectual. After his death in 1970, however, this image changed slightly. Older criticisms gained weight. Presser was still seen by some as a fellow traveller. Former student Richter Roegholt still could not understand why Presser in 1948 had refused to distance himself from the communist takeover in Czechoslovakia. ${ }^{71}$ Others disapproved of his critical attitude towards Zionism, being an assimilated Jew, although he had always supported the State of Israel. The fact that he preferred to be called Jacques instead of Jacob was often interpreted in this light. Even his modesty was now seen with suspicious eyes. Why had he not dared to present himself as an equal to famous historians like Johan Huizinga, Jan Romein or Pieter Geyl? His former 
student at the Vossius Gymnasium, Karel van het Reve characterised Presser in these words: 'His timidity, his clumsiness, his introversion, [...] his respect for rank and standing [...] seem all to stem from his birth on the Waterlooplein as a child of a Jewish diamond worker's family, of which no one had more education than primary school' ${ }^{72}$ Gerard Kornelis van het Reve, Karel's younger brother and also a student at the Vossius Gymnasium, judged Presser in an even more perceptive way. He called Presser the 'nicest teacher we had', but suffering from a 'pathological need to be loved'. 'With all his humour, brilliance and erudition Presser never in his whole life developed tastes and judgements of his own' ${ }^{73}$ A sketch by publisher Johan Polak, a former student at the Joods Lyceum confirms this image: 'Jacques Presser is one of the most fascinating and at the same time most enigmatic persons I have known in my life'. Presser was according to Polak very friendly and polite, but he always kept a distance.

This impression of Presser is confirmed again and again. ${ }^{74}$ Former student R.J. Mokken wrote a portrait of Presser as university teacher (later they became colleagues). Mokken was invited home by Presser for an examination, which was not unusual then, where he was 'again the friendly, tactful and courtly, but by nature somewhat reserved person, which I knew from his lectures'. ${ }^{75}$ In his autobiography, historian Salvador Bloemgarten, student of Presser both at the Vossius Gymnasium and at the university, sketches a comparable portrait. ${ }^{76}$

Despite being a specialist of the genre, Jacques Presser did not have the perfect outillage mental to write an autobiography. Besides his personal barriers, every historian always has a problem writing an autobiography, as Jeremy Popkin has shown. Autobiography is an ambiguous genre between fact and fiction which brings uneasiness to historians, who are by profession used to separating the two spheres. ${ }^{77}$ It is thanks only to writer and film director Philo Bregstein, who persuaded Presser to tell his life story in front of his camera, that there is a full autobiography. This documentary, Dingen die voorbijgaan, was broadcast in May 1970 on Dutch television, made a great impression on the public and was highly praised by critics. An English version of the documentary followed, The past that lives. Both versions were in recent years restored and published on DVD. ${ }^{78}$ Bregstein also published an extended book version based on nine hours of recorded interviews. ${ }^{79}$

By leaving a visual egodocument, Presser was again ahead of his time. Around 1970 it was unusual for a historian to write, let alone to publish an autobiography. Only a few of his colleagues did so. Johan Huizinga wrote a rather impersonal Mijn weg tot de geschiedenis, published posthumously. ${ }^{80} \mathrm{Jan}$ Romein wrote an autobiography, which is still in his personal archive and was never published completely. ${ }^{81}$ Annie Romein-Verschoor published an extensive autobiography, which, according to her biographer, is so untruthful that it had to be discarded as a source.$^{82}$ Pieter Geyl wrote an unusually 
candid autobiography, which was only published recently. ${ }^{83}$ The next generation of Dutch historians produced more egodocuments, including Lou de Jong, E.H. Kossmann, H.W. von der Dunk, H.L. Wesseling and Bunna Ebels-Hoving. ${ }^{84}$ They are following an international trend, which should be encouraged. Egodocuments written by historians often shed light on their work, choices of subject and methods. It could even be useful to make writing an autobiography part of the curriculum for students. An early exercise would make historians more aware of their own 'conditions of vision', and of their motives, goals, biases and limitations.

\section{ABOUT THE AUTHORS}

Arianne Baggerman teaches history at the Erasmus University Rotterdam and is professor in the history of publishing and book trade at the University of Amsterdam. She is the author of Publishing Policies and Family Strategies. The Fortunes of a Dutch Publishing House in the 18th and early 19h Centuries (Brill 2013). She is also coeditor of Controlling Time and Shaping the Self. Developments in Autobiographical Writing since the Sixteenth Century (Brill 2011). With Rudolf Dekker she published Child of the Enlightenment, Revolutionary Europe reflected in a boyhood diary (Brill 2009).

Rudolf Dekker taught history at the Erasmus University Rotterdam. Recent publications are The Diary of Constantijn Huygens Jr, Secretary to Stadholder-King William of Orange (Panchaud 2016) and Family, Culture and Society in the Diary of Constantijn Huygens Jr, Secretary to Stadholder-King William of Orange (Brill 2013). He has also published about revolts, humour, and family history. Meer verleden dan toekomst. Geschiedenis van verdwijnend Nederland (Bert Bakker, 2008) is a short history of the Netherlands.

\section{NOTES}

1 Jacques Presser, Louter verwachting. Autobiografische schets 1899-1919. Amsterdam: De Arbeiderspers, 1985. We thank Salvador Bloemgarten, Philo Bregstein, Ellen Grabowsky (Stadsarchief Amsterdam), and René Pottkamp (NIOD). We thank Piet Blaas, Ed van Thijn and Sonja Vetter-Samuels, students of Presser, for allowing us to cite their lecture notes.

2 Nanda Van der Zee, Jacques Presser. Het gelijk van de twijfel. Een biografie. Soesterberg: Aspekt, 2002, first edition Amsterdam: Balans, 1988. On Presser as historian see also Connie Kristel, Geschiedschrijving als opdracht. Abel Herzberg, Jacques Presser en Loe de Jong over de jodenvervolging. Amsterdam: Meulenhoff, 1998, with English summary. See also Dienke Hondius, 'Afterword', in: Jacques Presser, Ashes in the Wind. The Destruction of the Dutch Jewry. London: Souvenir Press, 2010, second edition, with suggestions for further reading. Many students, colleagues and friends have left memories of Presser, nineteen are collected in Jan Romein, ed., Jacques Presser. Geschenk van vrienden bij zijn zestigste verjaardag. Amsterdam: J.M. Meulenhoff, 1959. 
3 Jacques Presser, 'Mijn eerste lesuur op het Vossiusgymnasium', Vulpes 33, 1966, nr. 4 (April), 9-12, repr. in: M.C. Brands et al, eds., Uit het werk van J. Presser. Amsterdam: Athenaeum-Polak \& Van Gennep, 1969, 9-11.

4 Peter Jan Knegtmans, Een kwetsbaar centrum van de geest. De Universiteit van Amsterdam tussen 1935 en 1950. Amsterdam: Amsterdam University Press, 1998, 278-281.

5 A list of Presser's more than 300 publications: Uit het werk van J. Presser, Athenaeum-Polak \& Van Gennep, Amsterdam, 1969.

6 Jacques Presser, Napoleon. Historie en legende. Amsterdam: Elsevier, 1946. Translation: Napoleon. Das Leben und die Legende. Stuttgart: Deutsche Verlags-Anstalt, 1977.

7 Jacques Presser, 'De kindermoord van Amsterdam. Anne Frank, "Het achterhuis", De Vrije Katheder 7 no. 16 (15 August 1947), 253.

8 Philip Mechanicus, In dépôt. Dagboek uit Westerbork, ed. J. Presser. Amsterdam: Polak \& Van Gennep, 1964. Translations: Waiting for Death. A Diary. London: Calder and Boyars, 1968, and Cadavres en sursis. Journal de camp de Westerbork (28 mai 1943 - 28 février 1944). Paris: Notes du Nuit, 2016.

9 Jacques Presser, Ondergang. De vervolging en verdelging van het Nederlandse Jodendom, 1940-1945, 2 vols. The Hague: Staatsuitgeverij, 1965.

10 Jacques Presser, Ashes in the Wind. The Destruction of the Dutch Jewry. London: Souvernir Press, 1968/New York: E.P. Dutton, 1969, reprinted with an afterword by Dienke Hondius, London: Souvenir Press, 2010.

11 Presser, Ondergang II, p. 523, 525. The chapter "Documentatie" is not included in the English translation Ashes in the wind.

12 Amsterdam, NIOD, Archief, Collectie 244, Europese dagboeken en egodocumenten. The descriptions of the accepted and refused diaries are in Archief 703, boxes 14 and 15 .

13 Dagboekfragmenten 1940-1945. Den Haag: Martinus Nijhoff, 1954.

14 Jacques Presser, 'Memoires als geschiedbron', in: Winkler Prins Encyclopedie, vol. VIII. Amsterdam: Elsevier, 1958, reprinted in Uit het werk van J. Presser, 277-282.

15 Jacques Presser, 'Clio kijkt door het sleutelgat', in Uit het werk van J. Presser, 283-295.

16 Jacques Presser, 'Joden en dagboeken', Tijdschrift voor Geschiedenis 83, 1970, (special issue on egodocuments), 226-237.

17 On Philp de Vries, see the autobiography of his daughter, Aletta Schreuders, De sleutel van de Rozengracht. Amsterdam: De Buitenkant, 2009, tr. My grandfather's key. Amsterdam: De Lairesse Books, 2012.

18 Presser's lecture notes are kept in the University Library of the University of Amsterdam, Bijz. Coll. Verz. Presser, Collegeaantekeningen egodocumenten, XXXA1-23.

19 Van Dale groot woordenboek der Nederlandse taal, ed. C. Kruyskamp (10th ed.) 2 vols. The Hague: Martinus Nijhoff, 1976, I, 617.

20 Gustav René Hocke, Das europaeische Tagebuch. Wiesbaden: Limes, 1963.

21 George Misch, Geschichte der Autobiographie. Leipzig: B.G. Teubner, 1907, Much later followed by Geschichte der Autobiographie. Bern: Francke, 1949-1970. 7 vols. In the last volume articles about later periods are included such as 'Die Autobiographie der französische Aristokratie des 17. Jahrhunderts', published in: Deutsche Vierteljahrschrift fuer Literaturwissenschaft und Geistesgeschichte 1, 1923, 172-213. Also: George Misch, Studien zur Geschichte der Autobiographie. Göttingen: Vandenhoeck und Ruprecht, 1954-1957.

22 Georges Gurvitch, The Spectrum of Social Time, Dordrecht: Reidel, 1964, tr. of La multiplicité de temps sociaux. Paris: Centre de Documentation Universitaire, 1958.

23 Simon van het Reve [semi-pseudonym of Gerard Kornelis van het Reve; later changed to Gerard Reve], De avonden. Een wintervertelling. Amsterdam: De Bezige Bij, 1947. Translations: Les soirs. Un récit d'hiver. Paris: Gallimard, 1970, Die Abende. Eine Wintergeschichte, Gifkendorf: Merlin Verlag, 2013, The evenings. London: Pushkin Press, 2016. Presser told Philo Bregstein that he valued Reve's autobiographic novel and short stories, but 
disliked his later fictional works, which he called 'so much substandard, that I have to reject them'.

24 This copy is the Reve Museum at the Public Library Amsterdam.

25 Jan Romein, 'Kinderstem', Het Parool, 3 April 1946.

26 Jan Romein, De biografie. Amsterdam: Em. Querido, 1946, 204.

27 Piet Blaas, Henk Hoetink (1900-1963), een intellectuele biografie. Recht en geschiedenis. Hilversum: Verloren, 2010, and on the Kalff family: Loe Maas, Pro patria. Leven en streven van Gerrit Kalff, 1856-1923. Hilversum: Verloren, 2010.

28 Gerrit Kalff Jr., Het Dietsche dagboek. Groningen: J.B. Wolters, 1935.

29 The sealed parcels were reclaimed by his wife, and are lost since then. Stadsarchief Amsterdam, letter dated 16 January 1956 signed by M. Kalff-de Vries Robbé.

30 George Gusdorf, La découverte de soi. Paris: PUF, 1948.

31 Jan Romein, De biografie. Amsterdam: Em. Querido, 1946, tr. Die Biographie. Einführung in ihre Geschichte und ihre Probleme. Bern: A. Francke, 1948; S. Dresden, De structuur van de biografie. The Hague: Daamen, 1956.

32 Mistinguett, Toute ma vie, 2 vols. Paris: Julliard, 1954, tr. Mistinquett, Queen of the Paris Night. London: Elek Books, 1954, Mein ganzes Leben. Züruch: Thomas Verlag, 1954.

33 Billie Holiday and William Duffy, Lady sings the Blues. New York: Doubleday, 1958. Dutch translation: Utrecht: A.W. Bruna, 1969.

34 On the Huygens diary, see Rudolf Dekker, Family, Culture and Society in the Diary of Constantijn Huygens Jr, Secretary to Stadholder-King William of Orange. Leiden: Brill, 2013, Series Egodocuments and History 5. A selection of entries: Rudolf Dekker, ed., The Diary of Constantijn Huygens Jr, Secretary to Stadholder-king William of Orange. Amsterdam: Panchaud, 2016. On the De Clercq diary, see Rudolf Dekker, Childhood, Memory and Autobiography in Holland from the Golden Age to Romanticism, London: Macmillan, 1999, 59-73.

35 George Santayana, Persons and Places. The Background of My Life vol. 1. New York: Scribner's Sons, 1944, 149. George Santayana, Persons and Places. New edition: The works of George Santayana, Cambridge Mass.: MIT Press, 1986, vol. 1, 145-146 ('Philosophic parenthesis and apology').

36 New insights in Arianne Baggerman, Rudolf Dekker and Michel Mascuch (eds), Controlling Time and Shaping the Self. Developments in Autobiographical Writing since the Sixteenth Century, Leiden: Brill, 2011, Series Egodocuments and History 3.

37 Mémoires de Joseph Fouché was published in 1824. Today the work is seen as Fouché's own work. Michel Vovelle, ed., Mémoires de Joseph Fouché. Paris: Imprimerie Nationale, 1993.

38 On this subject see: Rudolf Dekker, 'De conjunctuur van de historische vervalsing', $D e$ Gids 146 (1983), 461-466.

39 Frank Maloy Anderson, The Mystery of "A Public Man". A Historical Detective Story. Minneapolis: University of Minnesota Press, 1948.

40 Maksim Litvinov, Notes for a Journal, ed., E.H. Carr. London: A. Deutsch, 1955.

41 Achmed Amba, I was Stalin's Bodyguard. London: Frederick Muller, 1952.

42 Hitler et les femmes. Le journal intime d'Eva Braun. Paris: Chevalailé, 1948, The Private Life of Adolf Hitler. The Intimate Notes and Diariy of Eva Braun. London: s.n., 1949, Het intieme dagboek van Eva Braun, Den Haag: Confidentia, s.a. The hoax was written by the Austrian writer and film director Luis Trenker.

43 Jean-Paul Sartre, La nausée. Paris: Gallimard, 1938, Dutch translation: De walging. Roman. Amsterdam: Strengholt, 1950.

44 Johannes R. Becher, Aus andere Art so grosse Hoffnung. [East-] Berlin: Aufbau Verlag, 1951.

45 John Richard Hersey, The Wall. New York: Knopf, 1950, Dutch translation De muur Zwolle: Tijl, 1960.

46 Emmanuel Ringelblum, (1900-1944), Notes from the Warsaw Ghetto, ed. Jacob Sloan. New York: McGraw-Hill, French translation: Chronique du ghetto de Varsovice. Paris: Laffont, 
1959. Presser also mentioned Philip Freedman, Martyrs and Fighters. The Epic Story of the Warsaw Ghetto. New York: Praeger, 1954.

47 Maarten Brands, 'In memoriam Jacob Presser (1899-1870)', in his Het arsenaal van de geschiedenis. Over theorie en geschiedschrijving. Amsterdam: Wereldbibliotheek, 2013, 351-357, 353; cf. 'Romein en Presser. Eender maar vooral anders', ibid., 357-367.

48 Saul Friedländer, 'An Integrated History of the Holocaust. Some Methodological Challenges', in Dan Stone, ed., The Holocaust and Historical Methodology. New York: Berghahn Books, 2012, 181-189, 184. For his use of egodocuments, see Nazi Germany and the Jews, 2 vols. New York: HarperCollins, 1997-2007. About the use of diaries see also Peter Fritzsche, Life and Death in the Third Reich. Cambridge MA,: Harvard U.P., 2008. Dutch studies based on egodocuments are for example: Eva Moraal, Als ik morgen niet op transport ga... Kamp Westerbork in beleving en herinnering, Amsterdam: De Bezige Bij, 2014; Bettine Siertsema, Uit de diepten. Nederlandse egodocumenten over de nazi concentratiekampen, Vught: Skandalon, 2007; and Bart van der Boom, 'Wij weten niets van hun lot'. Gewone Nederlanders en de Holocaust, Amsterdam: Boom, 2012, which was criticised for its conclusions and its use of egodocuments: see Evelien Gans and Remco Ensel, 'De inzet van Joden als "controlegroep". Bart van den Boom en de Holocaust', Tijdschrift voor Geschiedenis 126, 2013, 388-396, and 564-570; and Michael Mascuch, Rudolf Dekker and Arianne Baggerman, 'Egodocuments and History. A Short Account of the Longue Durée', The Historian 78, 2016, 11-56, 39-42.

49 See for instance Philippe Lejeune, Les brouillons de soi. Paris: Seuil, 1998 and Pour l'autobiographie. Chroniques. Paris: Seuil, 1998.

50 Ed van Thijn, Het verhaal. Amsterdam: Meulenhoff, 2000. See also Idem, 'Memories of a hidden child. A personal reflection', in Chaya Brasz and Yosef Kaplan, ed., Dutch Jews as Perceived by Themselves and by Others. Leiden: Brill, 2001, 265-277.

51 Ed van Thijn, Achttien adressen. Amsterdam: Augustus, 2004.

52 David Koker, Dagboek geschreven in Vught, ed. Karel van het Reve. Amsterdam: Van Oorschot, 1977.

53 Hanny Michaelis, Lenteloos. Oorlogsdagboek 1940-1941, ed. Nop Maas. Amsterdam: Van Oorschot, 2016, and De wereld waar ik buiten sta. Oorlogsdagboek 1942-1945. Amsterdam: Van Oorschot, 2017.

54 Examples: Carry Ulrich, 's Nachts droom ik van vrede. Oorlogsdagboek 1941-1945, ed. Bart Wallet. Zoetermeer: Mozaiek, 2016; Mirjam Bolle-Levie, Ik zal je beschrijven hoe een dag er hier uitziet. Dagboekbrieven uit Amsterdam, Westerbork en Bergen-Belsen, ed. Johannes Houwink ten Kate, Amsterdam: Contact, 2003, tr. Letters never sent. Amsterdam, Westerbork, Bergen-Belsen. Jerusalem: Yad Vashem, 2014; Willem Willing, Afdrukken van indrukken. Dagboek en brieven uit Kamp Westerbork. Waalwijk: Stichting tot uitgave van het Dagboek, 2006.

55 Friedrich Weinreb, Collaboratie en verzet, 1940-1945. Een poging tot ontmythologisering, ed. Renate Rubinstein. 3 vols. Amsterdam: Meulenhoff, 1969, preface by Jacques Presser (VI-VI), introduction by Renate Rubinstein (VII-IX). German translation: Die langen Schatten des Krieges. Weiler im Allgau: Thauros Verlag, 1989.

56 W.F. Hermans, De donkere kamer van Damocles. Amsterdam: Van Oorschot, 1958, tr. The Dark Room of Damocles. London: Heinemann, 1962, reprinted London: Harvill Secker, 2007.

57 Pauline Micheels, De waarheidszoekster. Henriëtte Boas, een leven voor de Joodse zaak Amsterdam: Boom, 2016.

58 Rapport door het Rijksinstituut voor Oorlogsdocumentatie uitgebracht aan de minister van Justitie inzake de activiteiten van drs. F. Weinreb gedurende de jaren 1940-1945, ed. D. Giltay Veth and A.J. van der Leeuw 2 vols. The Hague: Staatsuitgeverij, 1976. 
59 Aad Nuis, Het monster in de huiskamer. Een analyse van het Weinreb-rapport. Amsterdam: Meulenhoff, 1979. On the discussion see Philo Bregstein, Over Jacques Presser. Soesterberg: Aspekt, 2006, 19-25.

60 Regina Grüter, Een fantast schrijft geschiedenis. De affaires rond Friedrich Weinreb. Amsterdam: Balans, 1997.

61 Niels Graaf, 'Professor Presser. Portret tussen universiteitsgeschiedenis en biografische schets', in L.J. Dorsman and P.J. Knegtmans, ed., De menselijke maat in de wetenschap. De geleerden(auto)biografie als bron voor de wetenschaps- en universiteitsgeschiedenis. Hilversum: Verloren, 2013, 97-115.

62 Jacques Presser, Moord in de Poort. The Hague: Van Hoeve, 1965.

63 Jacques Presser, Homo submergus. Een roman uit de onderduik, ed. and introduction Nico Markus, Amsterdam: Boom, 2010.

64 Jacques Presser, De nacht der Girondijnen (Amsterdam: Vereniging ter Bevordering van de Belangen des Boekhandels, 1957). The book was published anonymously, so the public had to guess who the author was. Second edition Antwerpen: De Eik, 1957, with a foreword by Abel Jacob Herzberg. Fourth edition 1975 Amsterdam: Meulenhoff, 1975 with an afterword by Philo Bregstein. Latest edition Amsterdam: Meulenhoff, 2007, with an afterword by Primo Levi, translated from the Italian edition. The book was translated into English: Breaking Point (London: Muller, 1958, reprinted 1992), new edition: The Night of the Girondists, foreword Primo Levi (London: Harvill, 1992). Other translations appeared in German (1959, reprinted 1994), Danish (1959), French (1990), Hebrew (2004) Norwegian (1959), Spanish (1959, reprint 2010), Czech (1963) and Swedish (1959).

65 Bregstein, Gesprekken met Jacques Presser, 120-121.

66 See for this interpretation Ulli Jessurun d'Oliveira, student of Presser at the Vossius Gymnasium, in a short documentary on the Internet: https://literatuurplein.nl/detail/ persoon/h-u-jessurun-d-oliveira/168381.

67 La notte dei Girondini. Milaan: Adelphi, 1977, reprinted 1996.

68 The story is told by Philo Bregstein, 'Actualiteit van Jacques Presser', in his Over Jacques Presser. Soesterberg: Aspekt, 2006, 17-19. The book is a collection of articles on Presser. See also Philo Bregstein, 'Jacob Presser (1899-1970). Between history and literature', in Dutch Crossing. Journal of Low Countries Studies 36, 2012, 69-85.

69 Presser, Ondergang, II, 525. The chapter 'Documentatie' is not included in the English translation Ashes in the wind.

70 Van der Zee, Jacques Presser, 227-228. Twee brieven uit Westerbork van Etty Hillesum, ed. David Koning. The Hague: Baker/Daamen, 1962. Publication of Hillesum's diaries followed in later years, Het verstoorde leven. Dagboek van Etty Hillesum, 1941-1943. Bussum: De Haan/Unieboek, 1981. English translation: An Interrupted Life. The Diaries of Etty Hillesum, 1941-1943. New York: Pantheon Books, 1983. The complete works, ed. Klaas A.D. Smelik and Meins G.S. Coetsier, 2 vols. Maastricht: Shaker Verlag, 2014.

71 Richter Roegholt, 'Denken aan Jacques Presser', De Gids 162, 1999, 460-474.

72 Karel van het Reve, 'Nooit op zijn gemak in menselijk gezelschap. Over de Autobiografische schets van Jacques Presser', Vrij Nederland 3 August 1985, cited in Bregstein, Over Jacques Presser, 28.

73 Gerard Reve [Gerard Kornelis van het Reve], Moeder en zoon. Amsterdam: Elsevier Manteau, 1980, 50, 53, cited in Bregstein, Over Jacques Presser, 28. See also Presser's negative judgement about Reve's fiction, ibid., 140.

74 Foreword in Van der Zee, Jacques Presser.

75 G.J. Mokken, 'Jacques Presser', in: J. Goudsblom, P. de Rooy and J. Wieten, eds., In de Zevende. De eerste lichting hoogleraren aan de Politiek-Sociale Faculteit in Amsterdam. Amsterdam: Het Spinhuis, 1998, 118-127. 
76 Salvador Bloemgarten, Memoirs, Ruben Bloemgarten and Jacques van Gerwen eds (Amsterdam: Waterbloem, 2018).

77 Jeremy D. Popkin, History, Historians, and Autobiography. Chicago: University of Chicago Press, 2005.

78 Dingen die voorbij gaan is included in a dvd-box edited by Bert Hogenkamp, Tijdsbeeld Nederland. Hoogtepunten uit de Nederlandse documentaire film, vol. 1. Hilversum: Nederlands instituut voor Beeld en Geluid, 2007. English version The past that lives. Waltham MA: National Center for Jewish Film, Brandeis University, 2007. See interview 'Bregstein over Presser over Presser' with Philo Bregstein by Ph. van Tijn in Algemeen Handelsblad 23 May 1970, Supplement.

79 Philo Bregstein, Gesprekken met Jacques Presser. Amsterdam: Athenaeum-Polak \& Van Gennep, 1972.

80 Johan Huizinga, Mijn weg tot de geschiedenis. Haarlem: Tjeenk Willink, 1947, new edition ed. Anton van der Lem, Nijmegen: Vantilt, 2016.

81 Instituut voor Sociale Geschiedenis, Amsterdam, Archief Jan Romein, 39, Autobiography 1893-1921, with additions. Much of the diaries and letters are destroyed or lost, see Bart Hageraats, 'Jan Romeins archief in het IISG', in Bart Hageraats, "Geloof niet was geschiedschrijuers zeggen...” Honderd jaar Jan Romein, 1893-1993. Amsterdam: Stichting beheer IISG, 1995, 87-115.

82 Annie Romein-Verschoor, Omzien in verwondering, 2 vols. Amsterdam: Arbeiderspers, 1971, see also Angenies Brandenburg, Annie Romein-Verschoor, 1895-1978. Amsterdam: Arbeiderspers, 1988.

83 Pieter Geyl, Ik die zo weinig in mijn verleden leef. Autobiografie 1887-1940, ed. W.J. Berkelaar et al. Amsterdam: Wereldbibliotheek, 2009.

84 Lou De Jong, Herinneringen, 2 vols, The Hague: SDU, 1993-1996; E.H. Kossmann, Familiearchief. Amsterdam: Bakker, 1998; H.L. Wesseling, Zoon en vader, vader en zoon. Amsterdam: Bakker, 2008; H.W. von der Dunk, Terugblik in strijklicht. Jeugdherinneringen. Amsterdam: Bert Bakker, 2008; Bunna Ebels-Hoving, Geschiedenis als metgezel. Hilversum: Verloren, 2011. 